\title{
EUROPEAN INTEGRATION PROCESSES IN POST-EUROMAIDAN UKRAINE: IN SEARCH FOR SCENARIOS
}

\author{
Vadym ZHELTOVSKYY, PhD \\ Faculty of Political Science and International Studies, University of Warsaw, Poland \\ v.zheltovskyy@uw.edu.pl
}

\begin{abstract}
The article makes an attempt to explain key developments of the European integration processes in the aftermath of Euromaidan events in Ukraine. The analysis covers brief summary of the above mentioned processes in years 1994-2004 and puts major emphasis on the directions and peculiarities of the EU-Ukraine cooperation concerning deliberation and introduction of democratic reforms as well as the main impediments to their successful implementation. The methodology of the research is predominantly based on the method of scenarios aiming to give arguments in favor and against the most probable directions of further relations between Ukraine and the EU. As a matter of fact, on the grounds of the conducted study of political and social situation in Ukraine as well as the policies and position of the European Union and Russian Federation toward the European integration of Ukraine, three scenarios are proposed with a view to evaluating the potential directions of Ukraine's development: 1) successful European integration and a full EU membership; 2) successful European integration without the perspective of a full EU membership; 3) the change of Ukraine's pro-European course. Finally, the conclusive remarks summarize of the most significant developments in reference to the systemic reforms launched in 2014 and a set of recommendations regarding the perspective steps that would bring Ukraine closer to the European Union.
\end{abstract}

Keywords: European integration, Europeanization, Association Agreement, anti-corruption reforms.

\section{Introduction}

The issue of European integration has been on political agenda of the Ukrainian authorities since Ukraine regained its independence in 1991. The most recent and dramatic example attesting to the topicality of integration with the European Union (EU) was refusal by Viktor Yanukovych to sign the Association Agreement (AA) in 2013, which led to protests in Independence Square in Kyiv known as Euromaidan. ${ }^{22}$ Therefore, the purpose of the article is to explain the mechanisms

${ }^{22}$ The term "Euromaidan" is used in reference to a series of anti-government protests in Ukraine which began on 21 November 2013 in Maidan Nezalezhnosti (in English:, "Independence Square") in Kyiv, as a reaction to the government's decision to withhold from association with the EU. 
of cooperation between the EU and Ukraine which resulted in particular political decisions in PostEuromaidan period. In reference to the stated purpose, the major research tasks are the following:

- to analyze the key stages of the European integration processes in Ukraine in 1991-2018;

- to evaluate the current state of Ukrainian reforms in context of the EU integration criteria;

- to explain the possible scenarios of European integration of Ukraine.

Furthermore, the article makes an attempt to verify the main hypothesis stating that the success and the scale of the Ukraine's European integration greatly depends on the cooperation mechanisms between the European and Ukrainian policy-makers as well as on the involvement of representatives of civil society and scholars in the reforming processes. Meantime due to the dynamic nature of the process, such factors as political and social situation in Ukraine, level of the EU engagement and the Russian position toward the issue of Ukraine's integration with the European Union seem to have a considerable impact on the choice of scenario regarding the direction of transformation process in Post-Euromaidan Ukraine in the nearest future.

As far as the methodology of the article is concerned, the research purpose, tasks and hypothesis determine the use of a certain set of methods. It is the method of scenarios that is supposed to give arguments in favor and against the most probable directions of further relations between Ukraine and the EU. Thus, the article analyzes the political and social circumstances in Ukraine that have impact on the vector and pace of the reforms and are directly connected with the prospects of European integration. As regards other methods used in the political science research, the structure of the paper is based on the comparison of major political actions and decisions aimed at adoption of legal regulations and changes necessary to meet the requirements set by the EU institutions. In addition to the comparison, the historical method is used in order to explain the essence of analyzed political actions and their outcomes for the perspectives of Ukraine's European integration in different periods of state's independence.

\section{Literature Overview}

Prior to the analysis of the European integration prospects of Ukraine, it is important to analyze the available definitions of such terms as European integration, Europeanization and external Europeanization, and the state of scientific research in given field.

Overall, experts agree that the concept of European integration has a wide range of meanings and interpretations. Konstanty Adam Wojtaszczyk (2015, p. 103) underlines such 
elements of its definition as peaceful and voluntary nature of unity between societies, political and legal systems of member states "at the level of common values and standards". Dariusz Milczarek (2012, pp.28-29) defines "exceptionally unique and greatly complex nature" as major feature of the EU. According to the author, the European values based on the principles of democracy and human rights have become a specific feature that is associated with the EU and that makes the EU a unique entity. Consequently, the EU has a reputation of a democracy advocate and support provider for the rest of the world.

Similarly, the term Europeanization has "many faces" as well. Almost two decades ago, Johan Olsen (2002, pp.921-952) offered five uses of this term: 1) as territorial expansion of the EU/Europe; 2) as institutionalization on European level; 3) as a transfer of norms and regulations outside Europe; 4) as a political action aimed at strengthening the integration; 5) as changes of state and regional system of management. More recent definitions describe Europeanization as the impact of Europe, or the process of European integration in the context of the EU's impact on the political systems of its Member States (Miecznikowska, 2018, p. 39).

Concerning the impact of Europeanization, Radaelli and Pasquier (2006, p. 46) assert that Europeanization might have a varied impact on domestic structures overall or on their components, be it state-building, development of capitalism, democratization, nation-formation or development of welfare systems. According to Nadalutti (2015, p.39), some studies have shown that using different channels has had both domestic and local impact: with the help of institutional models, which should be taken into account by governments at national and subnational levels; with the help of EU policy implementation at the domestic and local level that resulted in the change of balances of power inside particular countries; or with the help of winning hearts and minds of social actors at the local level. In his turn Bartolini (2005, p.389) summarizes that the essence of the Europeanization hypothesis lies in cross-border coordination among different actors with similar interests.

In regard to the dimension of the Europeanization process, Konstanty Adam Wojtaszczyk (2018, p.288) highlights its two major forms in the EU member states: 1) downloading - in the sense of the transfer of preferences from the level of the EU to the level of a member state; 2) uploading - or the transfer of state preferences to the level of the EU. In this context, Tanja Borzel $(2010$, p.8) states that the top-down perspective seems to be relevant in reference to the states with a weak position in the EU decision-making process. Apart from the vertical dimension, scholars 
point to the horizontal dimension of this process (cross-loading), meaning the transfer of European standards and regulations between the states without direct participation of the EU institutions (Miecznikowska, 2018, p. 41).

As regards the European integration of non-EU countries, the emphasis should be put on the Eastern policy of the EU and the Eastern Partnership program in particular. As Ruszkowski puts it (2019, p. 203), while studying the issue of Europeanization and its impact on institutions, states or regions, one should take into account the influence of the Europeanization on other actors of given process such as people, social groups, or elites. From this perspective, a group of authors analyze the issue of the external Europeanization. Olga Barburska (2018, pp.188-189) summarizes that external Europeanization involves the transfer of EU standards and regulations to candidate states that are expected to adjust their political systems in order to meet the membership criteria. Rafał Riedel (2010, p.237) adds that the external Europeanization is likely to foster the dynamic of integration processes in the candidate states.

Due to the stated purpose and hypothesis, the article research is based on the concept of external Europeanization that is understood as transfer of European norms and regulations aimed at the transformation of Ukrainian system of governance on the one hand, and the impact on the role of political and social actors in Ukraine in transformation processes on the other.

\section{European Integration Processes in Ukraine in 1994-2014}

The 21st EU-Ukraine summit in Kyiv on 8 July 2019 included joint political statements on "the strength of the political and economic ties between the EU and Ukraine". In fact, a general overview of the implementation of the AA demonstrates that the "progress of performance of the scheduled objectives in 2018 increased by $11 \%$ against 2017 and amounted to 52\%" (Consilium.Europa.EU, 2019). Additionally, the number of Ukrainians supporting integration with the EU has been constantly growing and increased from $48 \%$ in 2013 to $69 \%$ in 2019 while $63 \%$ of Ukrainians expressed a high level of trust towards the EU as a strategic partner of Ukraine (Eurointegracijnyy portal, 2019).

Meanwhile, former Vice-Speaker of the Ukrainian Parliament Oksana Syroyid, in her keynote lecture at the XXIV Ukrainikum summer school at the University of Greifswald entitled “Geopolitics, war and Ukraine's success", presented a viewpoint on EU-Ukraine cooperation 
stating that the EU should „open the door” for Ukraine. ${ }^{23}$ This article makes an attempt to explain the major milestones of the EU-Ukraine cooperation since 1991 in order to understand whether, using the door metaphor, the door is more opened now than it was before.

It is in fact year 1994 that might be regarded as a starting point of the EU-Ukraine relations, when the Partnership and Cooperation Agreement between the European Communities and their Member States, and Ukraine, adopted on 14 June 1994, provided the framework for cooperation between the two parties in such areas as political, trade and economic relations (EC.Europa.EU, 2019). However, the document entered into force only in 1998.

As regards the relations between the EU and Ukraine in 1994-2014, the relations during the Kuchma's presidencies are described by Taras Kuzio $(2006$, p.89) as "troubled" due to multivectorism of Ukraine's foreign policy. Interestingly, Oleksiy Haran and Maria Zolkina (2014, pp.1-2) argue that multivectorial navigation by Kuchma was eventually slightly dominated by the direction toward the West, pointing to such documents as "Strategy for Ukraine's Integration into the EU" issued in June 1998, and "Law on Fundamentals of National Security in Ukraine" drawn up at the end of Kuchma's second term that declared joining the EU and NATO as aims of the Ukrainian state and were unanimously supported by the parliamentary faction of the Party of Regions whose leader Viktor Yanukovych served as the Prime Minister of Ukraine at the time. On the other hand, Kataryna Wolczuk (2003, pp.1-3) argues that such political steps as the ones mentioned above were only "declarative Europeanization", while in reality the Ukrainian authorities were reluctant and/or unable to introduce the necessary changes and transform the political system of Ukraine in order to meet the criteria of European integration.

In terms of changes after the 2004 Orange revolution, Kuzio uses the same metaphor as Syroyid in her lecture, stating that the EU door for Ukraine remained closed. The EU approach to Ukraine after the Orange revolution was based on the European Neighbourhood Policy that was supposed to create an Action Plan for every member. Ukraine found itself placed on the same level as Northern African states, Israel, or Russia - countries that either were not part of Europe at all, or have never declared their willingness to become part of the EU (Kuzio, 2006, p.90). Despite the official pro-Western position of Viktor Yushchenko and the actions demonstrating the pro-

\footnotetext{
${ }^{23}$ based on the author's notes from the keynote lecture by Ms. Oksana Syroid on 5 August 2019 at the Alfred Krupp Wissenschaftskolleg Greifswald as part of the XXIV Ukrainian Summer School "Ukraine's Forced Choice".
} 
European approach, such as lifting the visa requirement for EU citizens, there were no similar actions in response from Brussels. Meantime, a positive change for Ukraine was joining the World Trade Organization in 2008 that was one of the foreign policy aims of president Yushchenko (Haran and Zolkina, 2014, p.3). Furthermore, in 2009 Ukraine officially joined the Eastern Partnership initiative of the EU which focused on four main elements: association with the EU, creation of a Deep and Comprehensive Free Trade Area (DCFTA), dialogue on the establishment of a visa free regime, and energy cooperation (Szeptycki, 2014, p.4).

Finally, relations between the EU and Ukraine in 2010-2013 involved a number of significant developments. Viktor Yanukovych was sending mixed signals to the West. His Party of Regions initiated and supported a new law that introduced the non-block policy, thereby excluding integration with NATO on the one hand, and leaving integration with the EU as a priority of Ukraine's foreign policy on the other. At the same time, Russia took a series of steps to convince Yanukovych to join the Customs Union with the former Soviet States. Finally, Yanukovych made a decision not to sign the AA with the EU in November 2013 and accepted a significant financial assistance of 3 billion dollars from Russia. This financial incentive was a considerable argument for the Ukrainian government in the light of political declarations of Prime Minister Azarov that the AA would lead to Ukraine's bankruptcy (Szeptycki, 2014, p.14). Yanukovych's decision led to mass protests of Ukrainians who demanded signing the AA with the EU, and a dramatic development of Euromaidan events leading to the escape of Yanukovych, annexation of the Crimean peninsula and the military conflict in Donbas.

\section{EU-Ukraine Relations in the Post-Euromaidan Period}

Prior to the analysis of the EU-Ukraine relations in the light of the AA implementation, the following part concentrates on the brief explanation of the official position of the EU concerning the Ukraine's declarations of its pro-European course and negative attitude of some European politicians toward signing the AA with Ukraine in 2014.

In their reflections on the process of external Europeanization, mentioned in the previous part of this article, a number of scholars speak about the principle of conditionality. On the one hand, the principle of conditionality is analyzed in reference to conditions that should be fulfilled by the candidate states in order to become a member of the European Union (Ruszkowski 2019, p. 184; Riedel 2010, p. 235; Skolimowska 2015, p. 71). On the other hand, it is underlined that the 
success of the conditionality in the case of ENP states is unlikely due to „effectiveness and democratic legitimacy of their domestic institutions" and no clear prospects for EU membership (Börzel 2011).

Meanwhile, Burlyuk and Shapovalova (2017, p. 36) address the issue of conditionality in reference to the EU performance toward Ukraine before 2014 stating that the case of Ukraine demonstrated "two faces" of given principle: in addition to government as a target group of the conditionality principle, the impact is put on the civil actors observing the EU policies. Therefore, it is of equal importance for the EU to build alliances with non-political actors on the domestic level of particular state. At the same time, according to Piskorska (2018, p.90), the offer of the European Union may be regarded as inadequate to the expectations of such countries from the Eastern Partnership Initiative as Ukraine. In fact, scholar points to the differences between the EU's enlargement policy requirements toward the Eastern European states and the states already aspiring to become the EU member states. Such lack of precision might result in discouragement of potential candidates in their attempts to join the European Union or even in changing the direction toward Russia.

As far as the ratification of the AA is concerned, the document was expected to be ratified by the EU institutions as well as all EU member states in accordance with their constitutional procedures. The position of the EU institutional leaders was unanimous. In their joint statement on 16 September 2014 José Manuel Barroso, President of the European Commission, and Herman Van Rompuy (2014), President of the European Council welcomed the simultaneous ratification of the EU-Ukraine Association Agreement in the Verkhovna Rada and in the European Parliament and considered it to be a significant step on the way to „Ukraine's transformation into a modern and prosperous European democracy". Similar ideas were expressed three years later after the ratification of the AA by all member states. The President of European Council Donald Tusk (2017) emphasized the benefits of the fully ratified AA for strengthening political and economic cooperation between two parts.

Despite the unanimous position stated above as well as successful ratification in all member states, it was the ratification process in the Netherlands that led to a delay in the finalization of the agreement. Even though the Approval Act for the ratification of the agreement was adopted by two Chambers of the Dutch Parliament: on 7 April 2015 by the House of Representatives and on 
7 July 2015 by the Senate respectively, its entry into force was influenced by referendum procedure (Van der Loo, 2016).

The referendum itself took place on 6 April 2016 resulting in $61 \%$ of the Dutch voters saying „no" to the ratification of the AA between Ukraine and the European Union. Despite the fact that the referendum had low turnout (32\%) and did not have a binding character for the Dutch authorities, it did influence the ratification process in the Netherlands and the negotiation on the wording of the AA regarding the prospects of the EU membership for Ukraine. In fact, the referendum outcomes were seen as anti-EU signal and as ,an embarrassing blow” to the Dutch government who was in charge of the rotating EU presidency at the time (Euractive 2016).

Finally, the Netherlands ratified the EU-Ukraine AA a year later, on 30 May 2017 with the support from two-thirds of the senate and opposition coming mostly from far-left and far-right parties. At the same time, the positive vote came after the negotiation on the wording of the document initiated by the Dutch Prime Minister Rutte in December 2016 at the EU summit. Based on the referendum results, Rutte successfully argued for the need to adopt the annex to the AA stating that the EU membership is not guaranteed to Ukraine, and that the Netherlands is not obliged to provide Ukraine with military assistance. Meanwhile, the Head of the European Commission Jean Claude Juncker regarded the positive vote of the Dutch parliament as ,an important signal" to Ukrainian counterparts ensuring them that they are welcome in Europe (EU Observer 2017).

Interestingly, the AA consists of 1200 pages on which 1943 tasks in 27 areas have been presented. Parts of the AA have been provisionally introduced since 1 November 2014 while the Agreement as such came into force on 1 September 2017 (EU-UA.org, 2019). The analysis below summarizes the major changes that have taken place or are in the process of implementation in terms of the AA. The emphasis is put on the reform processes in regard to the constitutional and anti-corruption reforms that directly or indirectly influence all sectors mentioned in the AA, and are crucial for the democratic development of Ukraine.

\section{Constitutional reform}

The constitutional reform was declared to be one of the most important for the transformation of Ukraine, on its path to integration with the EU. What is more, President Petro Poroshenko initiated the discussion on the constitutional amendments aimed at establishing 
Ukraine's strategic course toward its full membership in the EU and NATO in the Preamble of the Constitution which was supported by 334 members of parliament on 7 February 2019 (Evropeyska Pravda, 2019). The analysis below takes into account such reforms as the reform of decentralization and local self-governance and the judicial reform, in order to explain the political developments in relation to the constitutional reform in 2014-2018, and to evaluate the prospects of European integration for Ukraine in the nearest future.

As far as the Constitutional reform of Ukraine is concerned, the parliamentary debate on Bill number 2217 On Amendments to the Constitution of Ukraine (concerning the decentralization of power proposed by President Poroshenko) vividly illustrated the complexity of the Ukrainian political scene. The document was a topic of discussion on many domestic and foreign forums, including the discussions between Ukrainian top officials and leaders of the Normandy format or the European Venice Commission, whose Head described it as probably the only real approach that was possible in the existing situation (The Insider, 2015).

However, the fragment of the document stating that "peculiarities of local governance in certain districts of the Donetsk and Lugansk regions are defined by a separate law" led to a major disagreement in the Ukrainian parliament. More dramatically, after the vote which resulted in 265 votes in favor of the bill, there was an attempt to storm the parliament building by the protesters. As a result of a grenade attack, four soldiers from the National Guard were killed and more than 150 people, mainly members of law enforcement agencies, were injured (Olszański, 2015).

At the same time, a number of legal initiatives were successfully adopted in relation to transformation of local governance in Ukraine. These changes included voluntary amalgamation and the status of the starosta (head) of villages and settlements. In fact, the amalgamation of hromady into larger territorial communities facilitates their more effective management and creates conditions for a more successful implementation of local initiatives. As a matter of fact, the number of amalgamated communities has been constantly growing since 2014 and by July 2019, 924 amalgamated territorial units have been created. Thus, as of July 2019, almost 30\% of the Ukrainian population lived in amalgamated territorial units (decentralization.gov.ua, 2019). However, full decentralization of power is impossible without the constitutional amendments to the Ukrainian Constitution (Zheltovskyy, 2019, p.100).

In terms of the judicial reform, on 2 June 2016335 Ukrainian MPs adopted the constitutional changes in this regard. Among the main principles of the judicial reform were the 
return to the three-layer judicial system, establishing the Supreme Council of Justice, mandatory re-attestation of all Ukraine's judges, mandatory asset declaration for judges and their family members as well as stripping them off the immunity (Ukraine Crisis Media Centre, 2019).

Unlike the judicial reform, the bill amending the constitution concerning the local selfgovernment reform was never submitted to the second voting. Therefore, it remains to be seen whether the constitutional amendments regarding the decentralization and self-governance will take place in the nearest future.

\section{Anti-corruption reforms}

As Anders Aslund (2014, pp.64-66) asserted in his article Oligarchs, Corruption, and European Integration, in the aftermath of the 2014 Euromaidan events "the endemic corruption" appeared to be the most significant informal institution in Ukraine that exerted considerable impact on the political and economic life of the Ukrainian state. The analysis of legal acts and civil initiatives introduced since 2014 by both members of the Ukrainian parliament and civil society activists may thus provide an insight into the directions of anti-corruption actions. The analysts from the Reanimation Package of Reforms organization define the following four goals of the anticorruption reform: 1) comprehensive system of criminal punishment for corruption offenses; 2) effective system of corruption prevention in the public sector; 3) effective state supervision over the right to access public information; 4) effective measures against political corruption (Anticorruption reform).

In this regard Vox Ukraine research analyst Olga Rybak (2019) points out that from 2015 to 2019102 regulatory acts in the framework of anti-corruption reform were adopted. Among the most successfully implemented laws aimed at the fighting with corruption the analysts depict the reforms that concentrate on establishing mechanisms for open access to information connected with the state and local budget expenses or functioning of the public servants that eliminate the risk of abusing power and thus lead to the minimization of corruption.

Having said that, the international analysis of corruption rates around the globe keeps indicating significant problems with corruption in Ukraine at present. Even though there has been a slow positive dynamic in comparison to year 2013 when Ukraine found itself on 144 position, according to the Transparency International research project Corruption Perception Index, in year 
2018 Ukraine was put on 120 position out of 180 countries and territories (Transparency International, 2019).

In addition, corruption remains the major impediment to foreign investment in Ukraine. Three consecutive annual surveys conducted in 2015-2018 by Dragon Capital, the European Business Association (EBA) and Centre for Economic Strategy (CES), demonstrated that widespread corruption and lack of trust in the judiciary remained among the most formidable obstacles to investment in Ukrainian assets. At the same time, respondents pointed to positive developments in Ukraine since 2014 such as: the steps undertaken in the fight against corruption, relaunch of the judicial system, and a tangible progress in separating politics from business. Among the main detrimental factors they mentioned potential political pressure on independent anti-corruption institutions and the National Bank of Ukraine, and rejection of democratic values (Dragon Capital, 2019).

As regards the most recent developments in the judicial system of Ukraine, the law on anticorruption court was adopted by the Ukrainian MPs and signed by President Poroshenko. In its official statement the EU called this step "a positive development" and "a significant step" in the fight against corruption, as well as "a key component" of the EU-Ukraine AA (eeas.europa.eu, 2019). At the same time, there were concerns expressed by domestic and international observers regarding the selection process for the 39 judges who would sit in the court (Freedom House, 2019).

\section{European Integration - Scenarios for Ukraine}

The analysis of major developments in Post-Euromaidan Ukraine has brought some ambivalent findings on the prospects of European integration. On the one hand, experts whose work is analyzed in the previous part of the article point to an unprecedented number of reforms since 2014, while on the other, the pace of their implementation as well as cases of political opposition toward the reform processes evoke negative responses from domestic and international observers. Such state of events makes the issue of Ukraine's European integration a debatable one, with a number of possible developments. Therefore, the article defines possible scenarios for the future directions of the EU-Ukraine relations. The scenarios proposed below are based on three key issues that have direct or indirect influence on the success and pace of the European integration of Ukraine: 
1) the political and social situation in Ukraine;

2) the EU approach toward its closer ties with Ukraine;

3) the Ukrainian-Russian relationship in the light of the European integration processes in Ukraine.

\section{Scenario 1 - successful European integration and a full EU membership}

The first scenario argues for the likelihood of plausible grounds for the successful European integration with a full EU membership for Ukraine. To reach this objective a number of crucial criteria should be fulfilled. Following the logic of three key constituents of successful integration, there must be not only political consensus and social support for such step among the Ukrainian elites and civil society, but also international support or at least a lack of aggressive opposition toward such a step.

As far as the domestic situation in Ukraine is concerned, there has been a phenomenal political victory of Volodymyr Zelenskyy in presidential elections and his party Servant of the People in parliamentary ones. The landslide victory demonstrated a unique ability of Zelenskyy team to unite, in the election processes, Ukrainian people of different social and educational background and age. Such level of public trust, coupled with the declaration of President Zelenskyy to be only a one-term president, may serve as a significant incentive for speedy reforms aimed at combating corruption.

The presidential efforts to ensure independent functioning of anti-corruption institutions in Ukraine as well as to eliminate the political impact on the judicial system, and the newly established anti-corruption court in particular, together with professional appointments of the General Prosecutor and the Head of the Service of Security of Ukraine, will undoubtedly lead to continuation of anti-corruption policies and will speed up the pace of these processes. Furthermore, despite the potential disagreement in the Ukrainian parliament, the support for issues related to the EU integration may find the constitutional majority of 300 votes. All parties represented in Verkhovna Rada, with the exception of Opposition Platform "For Life", will most likely support the presidential initiatives to pursue pro-European policies.

The experience of Volodymyr Zelenskyy in conducting a professional media campaign seems to be of equal importance and might serve as an effective tool in promoting the benefits of becoming a part of the EU. Particularly, such campaigns could bring fruitful results in eastern and 
southern regions of Ukraine where the support for the accession is traditionally lower than in western or central parts of Ukraine. The high level of popularity of president Zelenskyy in these regions, as well as the fact that he originally comes from the city of Kryvyi Rig in eastern part of Ukraine, may act as additional positive factors contributing to the success of such campaign. The increase in public support for the closer ties with the EU will undoubtedly be another convincing argument in the negotiation talks on the international level.

As regards the position of the EU institutions, the democratic nature of the 2019 presidential and parliamentary elections in Ukraine and the continuation of anti-corruption reforms are likely to encourage the European officials to increase the level of support for Ukraine and bring the issue of its formal membership to the table. The recognition of the EU membership for Ukraine may be considered as a "wise move" that would serve as an incentive for modernization (Szeptycki, 2014, p.15). Additionally, the 13\% support for the pro-Russian party in the Ukrainian parliament might be a warning for the EU that more decisive steps are needed to persuade Ukrainians to support European integration. That, however, requires substantial financial support. Therefore, the increase of financial assistance for Ukraine and international investment may speed the process significantly. In the light of presidential promises to fight corruption as the main obstacle to international investments, such situation may be taken into account.

In terms of Russia's reaction to the potential prospect of Ukraine's full EU membership, the Ukrainian efforts alone may not be sufficient to reach consensus on the matter. In this context, the EU, Great Britain and the USA appear to be crucial partners in the negotiation with the Russian Federation. The unanimous position of the West on the one hand and the success of Volodymyr Zelenskyy in persuading a considerable majority of Ukrainian population (especially among Russian-speaking Ukrainians) to support the EU integration on the other may stop Russia from aggressive policies as a reaction to such step.

Scenario 2 - successful European integration without the perspective of a full EU membership

The second scenario argues that the European integration is likely to be successful without the prospects of the EU membership for Ukraine. Such a scenario seems to be a compromise for all three components that are taken into account. 
First, as far as the domestic political scene is concerned, pro-European policies might serve as a consolidating element for the former political rivals in the 2019 presidential elections, and create a strong pro-European coalition in Verkhovna Rada. At the same time, the domestic political actors who declare pro-European values as central to their programs, such as Petro Poroshenko or Sviatoslav Vakarchuk, may disagree with the perspective of European integration without membership, and criticize Volodymyr Zelenskyy and his party for insufficient actions towards a full membership in the EU. However, these parties will have to cooperate on integration efforts and if European integration turns out to be successful it may be a win-win situation for all of them, since all three might argue that their policies brought Ukraine closer to the EU standards.

Moreover, the second scenario of European integration without the membership prospects seems to be the most relevant from the EU perspective. The reasons for such approach have been the same since 1994. On the one hand, the EU has made an effort to reduce the Russian influence on Ukraine and encourage democratic mechanisms. On the other hand, the official authorities in Brussels might not be willing to deteriorate the already tensed relations with Russia by offering full EU membership to Ukraine. In this regard the AA states that the EU welcomes "European aspirations" of Ukraine but the document does not clearly state that the EU declares its political commitment to welcome Ukraine as a full member. Additionally, the EU could promote a closer Ukrainian integration with the EU Single Market that is not strictly connected with the membership requirement. In such a way the EU position in the Black Sea region might be strengthened as well (Szeptycki, 2014, p.2).

As for the Ukrainian-Russian relations under the conditions of closer ties with the EU, the developments might again directly depend on the international and domestic pressure on Russia. The West may present a solution which would include a compromise that respects Russian demands for not expanding the Western influence. Meantime, the EU might continue the strategic support for democratic mechanisms building in Ukraine in order to have a reliable partner that meets the criteria of an EU member state. Russia, on the other hand, might agree to such scenario presenting it as the strength of the Russian foreign policy that halted the expansion of the West and proved its hegemony in the region. Sooner or later, however, the question of a full membership might resurface, which will directly depend on how strong economically Ukraine will become and how fruitful the results of the reforms will be. 


\section{Scenario 3 - the change of Ukraine's pro-European course}

The third scenario suggests a failure of the European integration for Ukraine. Given scenario seems to be the most improbable due to the current political situation in Ukraine and a long tradition of pro-European aspirations among Ukrainians. As Alex Motyl argues, the reforms under the Poroshenko presidency established a new state "that is highly unlikely to tolerate too much incompetence or Russian interference" (Motyl, 2019). At the same time, this scenario takes into consideration the possible aspects that might negatively influence the willingness of Ukrainians to become a part of the EU.

As for the social support, this might greatly depend on the economic situation. The case of the 2019 presidential elections results proved that despite noticeable changes in many state-related areas and the launch of systemic reforms, public support may be easily lost if the level of corruption remains on the high level and the economic growth is not high enough to change the quality of life of an average citizen in a meaningful way. Therefore, if no substantial progress in implementation of anti-corruption reforms is made and if there is no transparent and objective investigation of criminal cases related to top corruption, there might appear a growing disappointment with the idea of European integration.

Additionally, professional propaganda techniques used by media and deliberately biased coverage of pro-European policies' failure, aimed at convincing the viewers of the necessity to stay either independent of the European influence or to build closer ties with Russia, may result in the increase of anti-European tendencies across Ukraine. In such a way, the issue of European integration might become a controversial topic leading to political and social disagreements that would disrupt the reform processes.

As for the position of the EU, the 2019 elections in Ukraine have brought new political actors who did not clearly state their foreign policy priorities during the election campaigns. Therefore, the EU authorities might decide to pause their active support for the Ukrainian counterparts, in order to observe the first political decisions and adjust own policies. Such pause may encourage Russia to take an advantage of the situation and escalate military conflict in further parts of Ukraine forcing president Zelenskyy to refrain from European integration strategies. 


\section{Conclusions}

European integration was regularly declared to be a priority aim of state development by the majority of political leaders in Ukraine. However, these declarations did not find reflection in their joint efforts toward the successful implementation of democratic reforms that would have overcome corruption and economic problems. Moreover, while the EU welcomed the declarations of Ukrainian politicians on the pro-European course, there were no considerable actions to support the transformation financially or to encourage the transformation processes by introducing procedures that would reinforce pro-European aspirations in Ukraine.

The nature of relationship between Ukraine and the EU has changed considerably after the dramatic Euromaidan events. One of the first actions of the Ukrainian authorities elected in 2014 was the adoption of the AA. Among other achievements was the abolition of visas for Ukrainian citizens with biometric passports, thus building closer ties between Ukraine and the EU. Another symbolic gesture made by the Ukrainian authorities was the constitutional amendment introducing the integration with the EU and NATO as a strategic goal for Ukraine.

Apart from that, the analysis of reforms launched and implemented since 2014 leads to the following conclusions:

- the number of crucial reforms for the democratic development of the state is higher than the number of reforms implemented in years 1991-2014, which illustrates the positive dynamic in the development of the legal basis for the transformation;

- key reforms directed at overcoming systemic corruption have been launched. Even though the implementation process is sometimes slow or blocked by officials, the pressure of civil society organizations and the EU officials has led to the positive dynamic in a number of cases. There has been a slow but positive change in the international evaluation of the corruption rate in Ukraine, which brings ambivalent conclusions on the pace of anti-corruption policies;

- joint efforts of Ukrainian lawmakers, civil society activists and international advisors led to discussions on such reforms as the judicial reform or the reform of local self-government in accordance with the European standards that fosters European integration by establishing legal mechanisms of preventing corruption, engaging civil society into the state building process and creating grounds for the economic development of the state;

- while there was a successful vote on constitutional amendments regarding the judicial reform, the example of decentralization reform illustrated the complicated nature of political 
disagreement over the part of the bill referring to peculiarities of local governance in occupied parts of the Donetsk and Lugansk regions, and raised further questions on the future of the proposal and timing for the second reading vote. At present, it remains to be seen whether the bill proposal will appear in the new parliament for the second vote.

The conclusions presented above give grounds to argue that there have been a significant number of positive developments in the European integration process in Ukraine since 2014. At the same time, the continued systemic implementation of anti-corruption policies is of crucial importance for the development of Ukraine and its successful integration with the EU. The nature of this integration remains dynamic and depends on political and social actors involved in the decision-making process. Therefore, different scenarios of events should be taken into consideration in order to successfully complete the democratic transformation of Ukraine's political system and avoid obstacles that could delay the process of the European integration.

\section{Acknowledgements}

The preparation of this article was financed in terms of the Program „DIALOG” of the Ministry of Science and Higher Education of Poland realized in years 2019-2021.

\section{References}

1. ASLUND, A. (2014) Oligarchs, Corruption, and European Integration, Journal of Democracy, Volume 25, No. 3, pp.64-73.

2. BARBURSKA, O. (2018) Polityka wschodnia Unii Europejskiej jako część sktadowa polityki zagranicznej UE, Warszawa: ASPRA JR.

3. BARTOLINI, S. (2005) Restructuring Europe: Centre Formation, System Building, and Political Structuring between the Nation State and the European Union, Oxford: Oxford University Press.

4. BARROSO, M., VAN ROMPUY, H. (2014) Joint statement on the ratification of the EU-Ukraine Association Agreement. Available from:

https://ec.europa.eu/commission/presscorner/detail/en/STATEMENT_14_280 [Accessed: 15/02/2020].

5. BORZEL, T. (2010) The Transformative Power of Europe Reloaded. Limits of External Europeanization, KFG Working Paper, No. 11, pp.3-25. 
6. BORZEL, T. (2011) When Europe Hits ... beyond Its Borders: Europeanization and the near Abroad, Comparative European Politics, No. 9, pp. 394-413.

7. BURLUYK, O., SHAPOVALOVA, N. (2017) “Veni, vidi, ... vici?” EU performance and two faces of conditionality towards Ukraine, East European Politics, No. 33, pp.3655. Available from:

https://www.tandfonline.com/doi/full/10.1080/21599165.2017.1280470 [Accessed: 15/02/2020].

8. CONSILIUM.EUROPA.EU (2019) EU-Ukraine summit, Kyiv, Ukraine. [Online] Consilium.Europa.EU. Available from: https://tiny.pl/tpg9h [Accessed:10/08/2019].

9. DECENTRALIZATION.GOV.UA (2019) Monitoring procesu decentralizaciji vlady ta reformuvannia miscevogo samovriaduvannia. [Online] Decentralization.gov.ua. Available from: https://decentralization.gov.ua/mainmonitoring\#main_info [Accessed: $1 / 08 / 2019]$.

10. DRAGON-CAPITAL (2019) Corruption and Distrust of Judiciary Top Investor Concerns for Third Year. [ONLINE] Dragon Capital. Available from: https://tiny.pl/tpgrb [Accessed: 3/08/2019].

11. EC.EUROPA.EU (2019) Summary of Treaty. Partnership and Cooperation Agreement between the European Communities and their Member States, and Ukraine. [Online] EC.Europa.EU. Available from: https://tiny.pl/tpgcg [Accessed: 11/08/2019].

12. EEAS.EUROPA.EU (2019) Statement by the Spokesperson on the Ukraine's adoption of the legislation to establish a High Anti-Corruption Court. [Online] EEAS.EUROPA.EU. Available from: https://eeas.europa.eu/delegations/ukraine/49325/node/49325 en [Accessed: 11/08/2019].

13. EU OBSERVER (2017) Netherlands ratifies EU-Ukraine treaty. [Online] EU OBSERVER.COM. Available from: https://euobserver.com/foreign/138060 [Accessed: 15/02/2020].

14. EURACTIV (2016) Dutch voters reject EU-Ukraine association. [Online] EURACTIVE.COM. Available from: https:/www.euractiv.com/section/globaleurope/news/dutch-voters-reject-eu-ukraines-association/ [Accessed: 15/02/2020]. 
15. EUROINTEGRACIJNYY PORTAL (2019) Kilkist ukrainciv jaki pidtrymujut vstup Ukrainy do ES iz 2013 roku zbilshylasia na 21\% - socdoslidzhennia. [Online] Eurointegracijnyy portal. Available from: https://tiny.pl/tpg9x [Accessed: 10/08/2019].

16. EU-UA.ORG (2019) Implementacija ugody pro asociaciju ta poriadku dennogo asociaciji Ukraina-ES. [Online] EU-UA.org. Available from: https://tiny.pl/tpgw6 [Accessed: 2/08/2019].

17. EVROPEYSKA PRAVDA (2019) Rada zminyla Konstytuciju ta zakripyla kurs Ukrainy na ES ta NATO. [Online] Evropeyska Pravda. Available from: https://tiny.pl/tpgch [Accessed:03/08/2019].

18. FREEDOM HOUSE (2019) Freedom House Report on Ukraine 2019. [Online] Freedom House. Available from: https://tiny.pl/tpgwv [Accessed: 05/08/2019].

19. HARAN, O., ZOLKINA, M. (2014) Ukraine's Long Road to European Integration, PONARS Eurasia Policy Memo No. 311. Available from:

http://www.ponarseurasia.org/memo/ukraine's-long-road-european-integration [Accessed: 10/08/2019].

20. KUZIO, T. (2006) Is Ukraine Part of Europe's Future?, Washington Quarterly, pp.89108.

21. MIECZNIKOWSKA, J. (2018) Europeizacja partii i systemu partyjnego Austrii, Warszawa: ASPRA JR.

22. MILCZAREK, D. (2012) The Origins of European Integration. In: ADAMCZYK, A., ZAJĄCZKOWSKI, K. (eds.) Poland in the European Union: Adjustment and Modernization. Lessons for Ukraine, Warszawa-Lviv.

23. MOTYL, A. (2019) Ukraine's Pretend President Now Faces a Real Test, Foreign Policy, Available from: https://tiny.pl/t5f3p [Accessed: 22/07/2019].

24. NADALUTTI, E. (2015) The Effects of Europeanization on the Integration Process in the Upper Adriatic Region, Springer.

25. OLSEN, J. (2002) The Many Faces of Europeanization, Journal of Common Market Studies, Vol. 40, No. 5, pp.921-952.

26. OLSZAŃSKI, T. (2015) Ukraine is divided over constitutional reform.Available from: https://tiny.pl/tpgw3 [Accessed: 07/07/2019]. 
27. PISKORSKA, B. (2018) The Eastern Partnership - a challenge for the EU's soft power in international relations, On-line Journal Modelling the New Europe, No. 26, pp. 7894.

28. RADAELLI, C., PASQUIER, R. (2006) Conceptual Issues In: PAOLO, G., MAARTEN, V. (eds.) Europeanization: New Research Agendas. New York: Palgrave Macmillan.

29. RIEDEL, R. (2010) Conditionality - czyli europeizacja otoczenia Unii Europejskiej. In: RIEDEL R., PACZEŚNIAK A. (eds.) Europeizacja - mechanizmy, wymiary, efekty, Oslo-Toruń-Wrocław.

30. RUSZKOWSKI, J. (2019) Europeizacja. Analiza oddziaływania Unii Europejskiej, Difin.

31. RYBAK, O. (2018) Antykorupcijna reforma: chogo naspravdi dosiagla Ukraina. Available from: https://tiny.pl/tpgcx [Accessed: 5/08/2019].

32. SKOLIMOWSKA, A. (2015) Potęga normatywna Unii Europejskiej w relacjach z państwami sąsiedzkimi. In: SKOLIMOWSKA, A. (ed.) Potęga normatywna Unii Europejskiej w obliczu umiędzynarodowionych konfliktów wewnętrznych, Warszawa.

33. SZEPTYCKI, A. (2016) Poland - Ukraine Relations, Revista UNISCI / UNISCI Journal, No. 40 , pp.57-76.

34. SZEPTYCKI, A. (2014) The European Union and the "Euromaidan" in Ukraine, Paper presented at the 8th General Conference of the European Consortium for Political Research, University of Glasgow, Glasgow, 3-6 September 2014, Available from: https://tiny.pl/t5f35 [Accessed: 7/07/2019].

35. THE INSIDER (2015) Projekt zmin do Konstytuciji zberigaje balans vlady - Glava Venecianskoi komisii. [Online] The Insider. Available from: http://www.theinsider.ua/politics/559bb0616c6fe/ (Accessed:19.07.2019].

36. TRANSPARENCY INTERNATIONAL (2019) Transparency International. Corruption Perception Index 2018. [Online] Transparency International. Available from: https://tiny.pl/tpgcm [Accessed: 3/08/2019].

37. TUSK, D. (2017) Remarks following the EU-Ukraine summit in Kyiv. Available from: https://www.consilium.europa.eu/en/press/press-releases/2017/07/13/tusk-remarkssummit-ukraine-kyiv/ [Accessed: 15/02/2020]. 
38. UKRAINE CRISIS MEDIA CENTRE (2019) Ukraine's Constitution: a permanent battlefield for politics. [Online] Ukraine Crisis Media Centre. Available from: https://tiny.p1/tpgct [Accessed: 20/06/2019].

39. VAN DER LOO, G., The Dutch referendum on the EU-Ukraine association agreement: legal options for navigating a tricky and awkward situation. Available from: https://www.ceps.eu/ceps-publications/dutch-referendum-eu-ukraine-associationagreement-legal-options-navigating-tricky-and/ [Accessed: 15.02.2020].

40. WOJTASZCZYK, K.A. (2018) Europeizacja państwa członkowskiego w Unii Europejskiej. In: PIETRAŚ, M., HOFMAN, I., MICHAŁOWSKI, S. (eds.) Państwo w czasach zmiany, Lublin.

41. WOJTASZCZYK, K.A. (2015) Crises in the Process of European Integration - Their Nature and Consequences. In: WOJTASZCZYK, K.A Crises in the Process of European Integration and Approaches to their Management, Warsaw:ASPRA JR.

42. WOLCZUK, K. Ukraine's Policy towards the European Union: A Case of 'Declarative Europeanization', Available from: https://tiny.pl/tpgc9 [Accessed: 23/06/2019].

43. ZHELTOVSKYY, V. (2019) Civil society as an actor in the political processes of local governance reform in Ukraine, Środkowoeuropejskie Studia Polityczne, Vol. 2/2019, pp.83-104. 